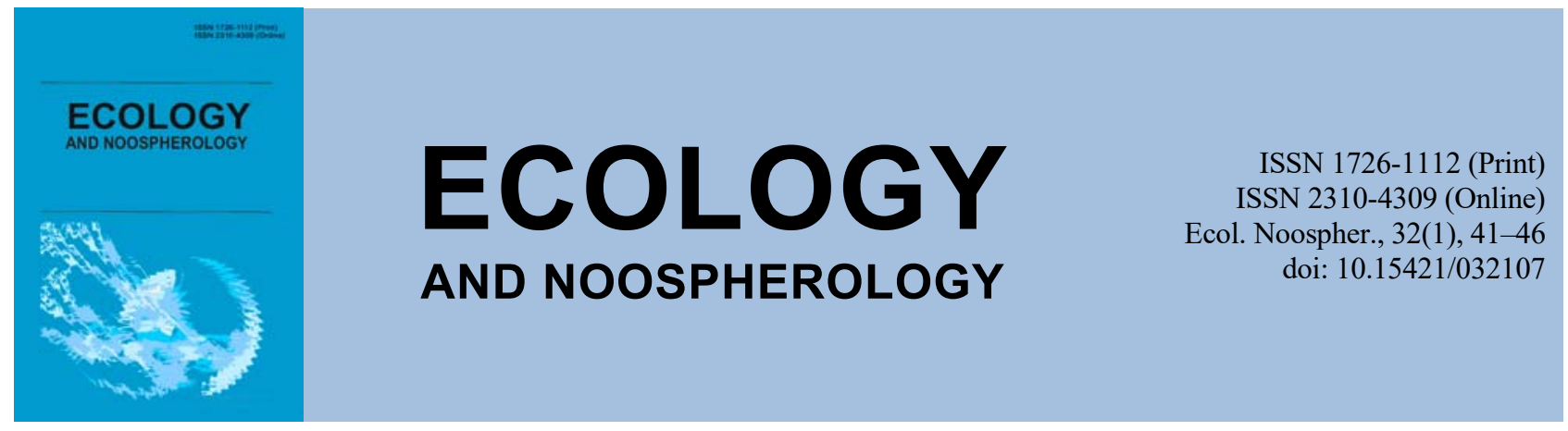

\title{
Characteristics of the toxic effect of imidacloprid on the state of Eisenia fetida (Annelida, Clitellata, Lumbricidae)
}

\author{
A. O. Huslystyi, V. Y. Gasso, S. V. Yermolenko, V. B. Petrushevskyi \\ Oles Honchar Dnipro National University, Dnipro, Ukraine
}

Article info

Received 15.04.2021

Received in revised form

19.04.2021

Accepted 14.05.2021

Oles Honchar Dnipro

National University,

Gagarin Ave., 72, Dnipro,

49010, Ukraine.

Tel.: +38-097-302-56-83

E-mail:viktor.gasso@gmail.com
Huslystyi, A. O., Gasso, V. Y., Yermolenko, S. V., Petrushevskyi, V. B. (2021). Characteristics of the toxic effect of imidacloprid on the state of Eisenia fetida (Annelida, Clitellata, Lumbricidae). Ecology and Noospherology, 32(1), 41-46. doi:10.15421/032107

\begin{abstract}
Imidacloprid became the most sold neonicotinoid insecticide in the world in the 21 st century. Due to their constant use, neonicotinoids are stored in soils, bottom deposits, and surface waters. It is known that neonicotinoids reveal toxicity for non-target species: annelid worms, insects, fish, birds, and mammals. Neonicotinoids exhibit reproductive toxicity, neuro-, hepato-, and genotoxicity for mammals. Earthworms are useful modeling organisms that are proposed to carry out toxicity tests. Eisenia fetida is considered a convenient and adequate species in toxicological studies. Analysis of available data shows that even low concentrations of imidacloprid caused protrusion of a belt, blackening, leakage of a cellar fluid, narrowing areas of the body with edema in segments, and dark body pigmentation in E. fetida. There are also biochemical changes. Low concentrations of imidacloprid $(<0.2 \mathrm{mg} / \mathrm{L})$ suppress the activity of cellulase. Imidacloprid also causes damage to DNA, production of reactive oxygen species, and alterations in antioxidant enzymes activity in E. fetida: inhibition of catalase, but activation of superoxide dismutase and glutathione-S-transferase. Imidacloprid reduces reproductive success in E.fetida, causing significant deformation of sperm, reducing the average number and size of cocoons and the success of birth. At concentrations $\geq 10 \mathrm{mg} / \mathrm{kg}$ of imidacloprid, the high mortality of worms makes it impossible for vermiculture. At $5 \mathrm{mg} / \mathrm{kg}$ of imidacloprid in plants remains for vermicomposting in seven weeks, the mortality rate of $25 \%$ of $E$. fetida individuals is fixed. The stereotypical escape reflex behavior in the worms was observed in relation to imidacloprid at a concentration of $1.32 \mathrm{mg} / \mathrm{kg}$. At the same time, molecular and cellular mechanisms of toxic effects of imidacloprid on E. fetida are almost not studied and needed special attention with further research.
\end{abstract}

Keywords: earthworm; neonicotinoid; insecticide; toxicity; morphological abnormalities; biochemical changes

\section{Характеристика токсичного впливу імідаклоприду на стан Eisenia fetida (Annelida, Clitellata, Lumbricidae)}

\author{
А. О. Гуслистий, В. Я. Гассо, С. В. Срмоленко, В. Б. Петрушевський
}

Дніпровський національний університет імені Олеся Гончара, Дніпро, Украӥна

Імідаклоприд став найбільш продаваним неонікотиноїдним інсектицидом у світі у XXI столітті. Завдяки постійному застосуванню неонікотиноїди зберігаються у грунтах, донних відкладеннях та поверхневих водах. Відомо, що неонікотиноїди виявляють токсичність для нецільових видів: кільчастих черв'яків, комах, риб, птахів та ссавців. Неонікотиноїди виявляють репродуктивну токсичність, нейро-, гепато- та генотоксичність для ссавців. Дощові черв'яки це зручні модельні організми, на яких запропоновано проводити тести речовин на екотоксичність. Eisenia fetida вважається зручним та адекватним об'єктом у токсикологічних дослідженнях. Аналіз доступних даних показує, що навіть низькі концентрації імідаклоприду викликають у E. fetida випинання пояску, почорніння, витікання целомічної рідини, звуження ділянок тіла 3 набряком у сегментах та темну пігментацію тіла. Спостерігаються також біохімічні зміни. Низькі концентрації імідаклоприду (<0,2 мг/л) пригнічують активність целюлази та супероксиддисмутази. пошкоджують ДНК, 
інтоксикація імідаклопридом викликає утворення реактивних сполук кисню та впливає на ферменти антиоксидантного захисту в E.fetida: інгібує каталазу, але активує супероксиддисмутазу та глутатіон-S-трансферазу. Імідаклоприд зменшує репродуктивний успіх у $E$. fetida, викликаючи значну деформацію сперматозоїдів, зменшення середнього числа та розмірів коконів та успішність народження. При концентраціях $\geq 10$ мг/кг імідаклоприду висока смертність черв'яків унеможливлює процес вермікомпостування. При 5 мг/кг імідаклоприду в рослинних залишках для вермікомпостування через сім тижнів зафіксовано смертність 25 \% особин E.fetida. Стереотипний поведінковий рефлекс втечі у черв'яків спостерігали по відношенню до імідаклоприду за концентрації 1,32 мг/кг. У той же час молекулярні та клітинні механізми токсичної дії імідаклоприду на E. fetida майже не вивчені та потребують особливої уваги при подальших дослідженнях.

Ключові слова: земляні черви; неонікотиноїд; інсектицид; токсичність; морфологічні аномалії; біохімічні зміни

\section{Вступ}

Неонікотиноїди стали популярними агрохімікатами для боротьби з популяціями шкідників у понад 120 країнах (EFSA, 2012; Goulson, 2013; Pisa et al., 2015). В якості обробки насіння неонікотиноїди потрапляють через коріння рослин, а потім системно транспортуються до інших частин рослини (Tomizawa, Casida, 2005; van der Sluijs et al., 2013). Вони викликають нейротоксичність у широкому діапазоні комах шляхом незворотного зв'язування з нікотиновими рецепторами ацетилхоліну, що призводить до паралічу та смерті (Tomizawa, Casida, 2005).

Імідаклоприд - це відносно новий системний інсектицид, що діє як агоніст нікотинових ацетилхолінових рецепторів (nAChR) та вважається заміною фосфорорганічних пестицидів (Jemec et al., 2007). Імідаклоприд став найбільш продаваним неонікотиноїдом у світі (Jeschke et al., 2011; Simon-Delso et al., 2015) і його глобальне використання для обробки насіння (Bonmatin et al., 2015) пояснюється значною ефективністю в боротьбі 3 широким спектром комах-шкідників (Jeschke et al., 2011; Goulson, 2013; Atwood et al., 2018).

Неонікотиноїди характеризуються низькою летючістю, високою проникністю та селективними інсектицидними властивостями (Casida, 2011; Jeschke et al., 2011; Ueyama et al., 2011; Iwafune et al., 2014; Song et al., 2018). Завдяки постійному застосуванню неонікотиноїди зберігаються у грунтах, донних відкладеннях та поверхневих водах (Goulson 2013; van der Sluijs et al., 2013; Bonmatin et al., 2015). Наприклад, імідаклоприд був виявлений у $97 \%$ зразків грунту 3 необроблених полів, на яких висівали оброблене імідаклопридом насіння кукурудзи (Bonmatin et al., 2005).

Імідаклоприд часто міститься в рослинах, вирощених у теплицях, оскільки цей системний інсектицид продається у 120 країнах для боротьби 3 різними видами білокрилок (Aleyrodidae) та попелиць (Aphidoidea) тощо при вирощуванні 140 різних сільськогосподарських культур, таких як помідори, перець, огірки, кабачки, картопля тощо (Hernández et al., 1999; Drobne et al., 2008;). Таким чином, тепличні рослини можуть містити імідаклоприд, який потрапляє до грунтів з їх відходами, що $є$ небезпекою для навколишнього середовища, оскільки має високий потенціал вимивання у грунтові води (WHO, 2006).

Відомо, що неонікотиноїди виявляють токсичність для нецільових організмів, що підтверджується їх токсичністю для медоносних бджіл та популяцій комахоїдних птахів (Tapparo et al., 2012; Whitehorn et al., 2012; Hallmann et al., 2014; Botías et al., 2015; Stanley et al., 2015).

Токсичність неонікотиноїдів для різних груп організмів, таких як ссавці, птахи, риби, комахи, кільчасті черв'яки тощо, вивчалась у багатьох дослідженнях (De Cant, Barrett, 2010; Luo et al., 1999; Renaud et al., 2018). Деякі 3 них $\epsilon$ високотоксичними для грунтових безхребетних (de Lima e Silva et al., 2017) і навіть демонструють сталість токсичності для виживання та розмноження протягом трьох поколінь (van Gestel et al., 2017). Останні дослідження доводять, що імідаклоприд може бути токсичним для бджіл і птахів (van der Sluijs et al., 2013; Gibbons et al., 2015; Pisa et al., 2015). Наприклад, імідаклоприд може порушити рух медоносних бджіл (Apis mellifera), погіршуючи рух крил і ніг (Medrzycki et al., 2003; Girolami et al., 2009) і спричиняти летальність при концентраціях до 0,1 мкг L-1 (Suchail et al,. 2001). Крім того, спостерігалося, що у червононогих куріпок (Alectoris rufa) знижувалась ефективність запліднення, виживання курчат та імунна відповідь після впливу імідаклоприду (Lopez-Antia et al., 2013).

Крім того, кілька досліджень in vitro та in vivo демонструють, що неонікотиноїди виявляють репродуктивну токсичність, нейро-, гепато- та генотоксичність для ссавців (Kimura-Kuroda et al., 2012; Gu et al., 2013; Cimino et al., 2017; Han et al., 2018).

Оскільки імідаклоприд токсичний для нецільових організмів у наземних екосистемах (Gibbons et al., 2015; Pisa et al., 2015), існує необхідність оцінити сублетальну токсичність імідаклоприду у грунтових організмах, таких як дощові черв'яки. Дощові черв'яки мають вирішальне значення для існування більшості наземних екосистем, оскільки вони підтримують фізичні, хімічні та біологічні властивості грунту (Edwards, Bohlen, 1992; Pisa et al., 2015). Оскільки імідаклоприд може зберігатися в грунті, дощові черв'яки, що там мешкають, можуть піддаватися його дії шляхом пасивної дифузії через шкіру або через травну систему (Edwards, Bohlen, 1992). Були проведені численні дослідження для оцінки токсичності імідаклоприду на дощових черв'яків (Luo et al., 1999; Zang et al., 2000; Dittbrenner et al., 2011; Wang et al., 2012, 2016; Zhang et al., 2014; Cang et al., 2017). Залишки імідаклоприду в грунті можуть здійснювати негативний вплив на нецільові грунтові організми, такі як дощові черв'яки (El-Naggar, Zidan, 2013; Smith et al., 2016).

Дощові черв'яки - це зручні модельні організми, на яких запропоновано проводити тести речовин на екотоксичність (EEC, 2003). Червоний каліфорнійський або тигровий, або гнойовий черв Eisenia fetida (Savigny, 1826) вважається зручним та адекватним об'єктом у токсикологічних дослідженнях (Wang et al., 2016; Gill et al., 2021).

У лабораторних тестах досліджуються такі ефекти екотоксикантів, як смертність, життєвий цикл при сублетальних концентраціях, ключові фізіологічні показники, регенерація та зміни ваги, а також поведінкові реакції. Зміни поведінки $є$ перспективними в екотоксикологічних дослідженнях, оскільки вони можуть викликати зміни на рівні екосистеми (Little, 1990; Doving, 1992; Scherrer, 1992). У випадку з дощовими черв'яками, оскільки їх корисна роль у грунтах напряму залежить від їх діяльності (риття нор та перетворення органічних речовин), надзвичайно важливо вивчити сублетальний вплив забруднюючих речовин, які можуть зменшувати активність дощових черв'яків. Однак вивчити поведінку дощових черв'яків складно, оскільки вони ведуть прихований спосіб життя.

На цей час існує багато екотоксикологічних методів використання дощових черв'яків для оцінки токсичності хімічних речовин (OECD, 1984). Про різні дослідження щодо екотоксикологічних механізмів дощового черв'яка щодо забруднюючих речовин, таких як важкі метали, пестициди (Stenersen, 1979) та комбіноване забруднення різних важких металів (Spurgeon, 2003), металів та сумішей пестицидів (Xu et al., 2006). 


\section{Поведінка неонікотиноӥдів у грунтах}

Неонікотиноїди мають тривалий період напіввиведення в грунтах, від кількох днів до понад 1000. Для імідаклоприду цей діапазон складає 28-1250 днів (для порівняння: в інших неонікотиноїдів: 7-353 дні - для тіаметоксаму; 148-6931 - для клотіанідину; 3-74 - для тіаклоприду, 31-450 днів - для ацетаміприду (Goulson, 2013). Виходячи $з$ цього, накопичення імідаклоприду може легко відбуватися при його багаторазовому використанні на сільськогосподарських ділянках (Bonmatin et al., 2015), що створює небезпеку для запилювачів та інших тварин, як безхребетних, так і хребетних.

\section{Температура середовища і токсичність імідаклоприду}

Підвищення температури середовища посилює гостру токсичність імідаклоприду для дощових черв'яків Eisenia fetida (Velki, Ecimovic, 2015). Однак хронічний вплив імідаклоприду на грунтову фауну досі детально не досліджено. Дані хронічного ефекту імідаклоприду важливі для оцінки екологічного ризику пестициду 3 урахуванням сценаріїв глобального потепління. Такий підхід до екотоксикологічних досліджень особливо важливий у тропічних регіонах (IBAMA, 1996). Крім того, місцеві грунти мають особливі фізичні та хімічні властивості, які впливають на токсичний потенціал хімічних речовин для грунтових організмів, а вплив кліматичних змін за останні десятиліття потребує більше уваги (Niva et al., 2016; Niemeyer et al., 2017; Daam et al., 2019). Bandeira et al. (2020) повідомляють, що токсичність імідаклоприду для E.fetida у тропічних грунтах зростає при більш високих температурах i це підвищення токсичності не залежить від хімічних та фізичних властивостей грунту. LC50 імідаклоприду, яка спостерігалася при 25 i $28{ }^{\circ} \mathrm{C}$, була вищою, ніж при $20^{\circ} \mathrm{C}$. Токсичність імідаклоприду в штучних сумішах була меншою, ніж у природних грунтах. 3 іншого боку, вплив властивостей грунту на показники токсичності імідаклоприду зменшувався при більш високих температурах.

\section{Морфологічні та біохімічні зміни у дощових черв'яків}

За даними Gill et al. (2021), у черв'яків під дією

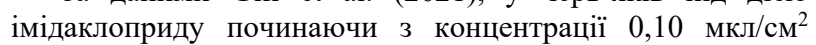
відбувається випинання пояску. Концентрація імідаклоприду 0,200 мкл/см ${ }^{2}$ викликала почорніння тіла та набряк сегментів. За концентрацій імідаклоприду 0,25 , $0,30, \quad 0,35$ та 0,40 мкл/см ${ }^{2}$ спостерігаються також почорніння тіла, пов'язане з витіканням целомічної рідини, звуженням ділянок тіла 3 набряком у сегментах, та темна пігментація.

Схожі зміни, які спостерігалися внаслідок дії імідаклоприду, також повідомлялися у E.fetida в дослідженні Kumar та Singh (2017). Вплив форату на E. fetida протягом 48 годин призвів до згортання та розриву стінок тіла, збільшення секреції слизу, викидання целомічної рідини, млявості та ураження поверхні тіла. Через атрофію стінка тіла дощового черв'яка тоншає, що призводить до некрозу та ерозії всієї стінки тіла, хоча таких змін у контролі не спостерігалося. Були відзначені значні епідермальні, морфологічні зміни, які спостерігалися після 48 годин впливу форату в концентраціях 20-40 мкл/см².

Низькі концентрації імідаклоприду $(<0,2$ мг/л) пригнічують активність целюлази, але можуть як активувати, так і інгібувати активність супероксиддисмутази (Luo et al., 1999). Zang et al. (2000) показали, що забруднення грунтів низькими дозами імідаклопріду (0,5 мг/кг) може викликати пошкодження ДНК у E.fetida. Продемонстровано, що хронічна інтоксикація імідаклопридом викликає утворення реактивних сполук кисню та впливає на ферменти антиоксидантного захисту в E. fetida: інгібує каталазу, але активує супероксиддисмутазу (СОД) та глутатіон-Sтрансферазу (Wang et al., 2016). За дослідженнями Zhang et al. (2014), імідаклоприд викликає різноспрямовані зміни в активності антиоксидантних ферментнів. Активність СОД стимулювалася обробкою з низькими дозами $(0,66$ мг/кг) імідаклоприду, тоді як високі дози (4,0 мг/кг) інгібують СОД. Окрім цього, більш тривалий вплив імідаклоприду також оцінювався як критичний чинник створення дисбалансу в активності антиоксидантних ферментів у E. fetida. Дослідження Gill et al. (2021) показало, що активність СОД виявилася прямо залежною від часу дії та концентрації пестицидів. Активність ферменту збільшується зі збільшенням концентрації імідаклоприду протягом 48 годин. За концентрацій імідаклоприду 0,195 мкл і 0,285 мкл активність СОД виявилася 6,773 та 7,263 од/мг білка відповідно, тоді як за концентрації 0,285 мкл імідаклоприду активність ферменту була 6,835 од/мг білка при 24-годинній експозиції.

\section{Вилив на ріст і розмноження черв'яків E. fetida}

За даними досліджень Fernández-Gómez et al. (2011), вага черв'яків E. fetida, що живляться гноєм великої рогатої худоби, суттєво змінюється з часом залежно від концентрації імідаклоприду в субстраті. Черв'яки, вирощені на гною з концентрацією імідаклоприду $\geq 2$ мг/кг, не збільшували свою вагу, тоді як значне збільшення біомаси особин $E$. fetida було зафіксоване при концентрації імідаклоприду 1 мг/кг так само, як і в контрольній групі.

Концентрація імідаклоприду 2 мг/кг у рослинних відходах не впливає на темпи росту та статеве дозрівання черв'яків, однак перешкоджає утворенню коконів статевозрілими черв'яками. Це свідчить про те, що імідаклоприд зменшує репродуктивний успіх у E. fetida. Luo et al. (1999) повідомили, що 0,5 мг/кг імідаклоприду у штучній грунтовій суміші спричиняе у E. fetida значну деформацію сперматозоїдів.

$\mathrm{Ge}$ et al. (2018) зазначають, що імідаклоприд мав значний вплив на один або декілька параметрів розмноження $E$. fetida. Середне число коконів та успішність народження зменшувалися. Суттєва дія імідаклоприду спостерігалась щодо середньої ваги коконів та успішності народження при $10 \%$-ній дії LC50 і вище (14 діб). Значно менші концентрації за LC50 гострої токсичності імідаклоприду впливали на успішність виходу E. fetida 3 коконів. Кількість новонароджених черв'яків виявилася найбільш чутливим показником впливу імідаклоприду. Крім згаданих вище показників, неонікотиноїди також впливали на розміри коконів.

\section{Вермікомпостування}

При концентраціях $\geq 10$ мг/кг імідаклоприду висока смертність черв'яків унеможливлює процес вермікомпостування, при якому використовуються черв'яки. При 5 мг/кг імідаклоприду через 7 тижнів у гної зафіксована смертність $25 \%$ особин. Це відрізняється від результатів досліджень із використанням штучного грунту, забрудненого 3,5 мг/кг імідаклоприду, де спостерігалася 50\%-на смертність у популяції E. fetida (Luo et al., 1999). Тобто токсичність імідаклоприду для E. fetida менша під час вермікомпостування, якщо використовуються оптимальні субстрати.

При вермікомпостуванні відходів томатів 3 теплиць у суміші без імідаклоприду черв'яки могли належним чином живитися цим субстратом, набираючи вагу, досягати статевозрілості і збільшувати чисельність. Наявність імідаклоприду у таких сумішах для вермікомпостування зменшувала кількість черв'яків, а також пригнічувала збільшення їх ваги порівняно 3 контрольною групою без імідаклоприду.

Мікроорганізми становлять основну частину раціону дощових черв'яків (Edwards et al., 1988). Як надійний біомаркер для негативного впливу пестицидів на 
мікробіоту при вермікомпостуванні використовують активність дегідрогеназ у грунтових сумішах (Benítez et al., 1999). Дегідрогенази - це ферменти, що беруть участь в окислювальному фосфорилюванні (García et al.,1997). Отже, зниження активності дегідрогенази, спочатку спричинене наявністю імідаклоприду у субстраті вермікомпостування, вказує на те, що цей пестицид пригнічує мікроорганізми. Цей негативний ефект може частково бути причиною гальмування росту черв'яків, що спостерігається у субстратах 3 імідаклопридом. Відновлення активності дегідрогенази після вермікомпостування свідчить про те, що цей процес зміг відновити раніше виснажений мікробоценоз (FernándezGómez et al., 2011).

\section{LC50 імідаклоприду для Eisenia fetida}

Luo et al. (1999) та Zang et al. (2000), працюючи 3 Eisenia fetida, показали, що через 14 днів LC50 імідаклоприду становив 2,3 мг кг 1 сухого грунту.

У 24-годинному тесті Chen et al. (2014) визначили LC50 імідаклоприду від 5,46 до 12,58 мг/кг, що на кілька порядків нижче, ніж бутахлор (гербіцид 3 групи ацетанілідів) та хлорпірифос (фосфорорганічний інсектицид). За результатами 48-годинного тесту імідаклоприд також показав найбільшу токсичність, значення LC50 становило 0,78-1,44 мг/кг.

\section{Поведінкові реакції}

Стереотипний поведінковий рефлекс втечі E. fetida спостерігали по відношенню до всіх неонікотиноїдів навіть при низьких концентраціях (4-20 \% ацетаміпріду, динотефурану, імідаклоприду, клотіанідину, нітенпіраму та тіаклоприду становив $0,77,0,91,1,32,0,14$, 0,55 та 7,87 мг/кг відповідно. Ці відмінності відповідали результатам тесту на гостру токсичність. Згідно з цими дослідженнями рефлекс втечі $E$. fetida на імідаклоприд спостерігався менше ніж у $60 \%$ випадків за цих концентрацій (Ge et al., 2018).

\section{Висновки}

Аналіз літературних джерел щодо впливу імідаклоприду на життєві показники дощових черв'яків показав, що вплив низьких концентрацій неонікотиноїдів впливає на ріст, розмноження, плодючість і поведінку E. fetida. Спостерігається суттєвий вплив навіть низьких доз імідаклоприду на ферментні системи антиоксидантного захисту, що може мати негативні наслідки на молекулярно-біохімічні процеси та взаємодії в клітинах червів. Оскільки дощові черв'яки вносять найбільшу кількість біомаси в грунти, слід приділити особливу увагу зменшенню використання неонікотиноїдів для сталого розвитку екосистем.

Молекулярні та клітинні механізми токсичної дії імідаклоприду на $E$. fetida майже не вивчені та потребують особливої уваги при подальших дослідженнях.

\section{References}

Atwood, L. W., Mortensen, D. A., Koide, R. T., Smith, R. G. (2018). Evidence for multitrophic effects of pesticide seed treatments on non-targeted soil fauna. Soil Biology and Biochemistry, 125, 144e155.

Bandeira, F. O., Alves, P. R. L., Hennig, T. B., Schiehl, A., Cardoso, E. J. B. N., Baretta, D. (2020). Toxicity of imidacloprid to the earthworm Eisenia andrei and collembolan Folsomia candida in three contrasting tropical soils. Journal of Soils and Sediments, 20, 1997e2007.

Benítez, E., Nogales, R., Elvira, C., Masciandaro, G., Ceccanti, B. (1999). Enzyme and earthworm activities during vermicomposting of carbaryl-treated sewage sludge. Journal of Environmental Quality, 28, 1099-1104.
Bonmatin, J. M., Giorio, C., Girolami, V., Goulson, D., Kreutzweiser, D. P., Krupke, C., Liess, M., Long, E., Marzaro, M., Mitchell, E. A. D, Noome, D. A., SimonDelso, N., Tapparo, A. (2015). Environmental fate and exposure; neonicotinoids and fipronil. Environmental Science and Pollution Research, 22, 35-67.

Bonmatin, J. M., Moineau, I., Charvet, R., Colin, M. E., Fleche, C., Bengsch, E. R. (2005). Behaviour of imidacloprid in fields. Toxicity for honey bees. In: E. Lichtfouse, J. Schwarzbauer, D. Robert (eds) Environmental Chemistry: Green Chemistry and Pollutants in Ecosystems. Springer, 483-494.

Botías, C., David, A., Horwood, J., Abdul-Sada, A., Nicholls, E., Hill, E., Goulson, D. (2015). Neonicotinoid residues in wildflowers, a potential route of chronic exposure for bees. Environmental Science and Technology, 49, 12731-12740.

IBAMA Ministério do Meio Ambiente. (1996). Portaria Normativa No 84, de 15 de outubro de 1996. Diário Oficial, 203, 21358-21366 (in Portuguese). http://www.ibama.gov.br/sophia/cnia/legislacao/IBAMA/P T0084-151096.pdf

Cang, T., Dai, D., Yang, G., Yu, Y., Lv, L., Cai, L., Wang, Q., Wang, Y. (2017). Combined toxicity of imidacloprid and three insecticides to the earthworm, Eisenia fetida (Annelida, Oligochaeta). Environmental Science and Pollution Research, 24, 8722-8730.

Casida, J. E. (2011). Neonicotinoid metabolism: Compounds, substituents, pathways, enzymes, organisms, and relevance. Journal of Agricultural and Food Chemistry, 59, 2923-2931.

Chen, C., Wang, Y., Zhao, X., Wang, Q., Qian, Y. (2014). Comparative and combined acute toxicity of butachlor, imidacloprid and chlorpyrifos on earthworm, Eisenia fetida. Chemosphere, 100, 111-115.

Chen, Y., Zang, L., Shen, G., Liu, M., Du, W., Fei, J., Yang, L., Chen, L., Wang, X., Liu, W., Zhao, M. (2019). Resolution of the ongoing challenge of estimating nonpoint source neonicotinoid pollution in the Yangtze River basin using a modified mass balance approach. Environmental Science and Technology, 53, 2539-2548.

Cimino, A. M., Boyles, A. L., Thayer, K. A., Perry, M. J. (2017). Effects of neonicotinoid pesticide exposure on human health: a systematic review. Environmental Health Perspectives, $125,155-162$.

Daam, M. A., Chelinho, S., Niemeyer, J. C., Owojori, O. J., De Silva, P. M. C. S., Sousa, J. P., Van Gestel, C. A. M., Rombke, J. (2019). Environmental risk assessment of pesticides in tropical terrestrial ecosystems: test procedures, current status and future perspectives. Ecotoxicology and Environmental Safety, 181, 534e547.

De Cant, J., Barrett, M. (2010). Clothianidin Registration of Prosper t400 Seed Treatment on Mustard Seed (Oilseed and Condiment) and Poncho/votivo Seed Treatment on Cotton. United States Environmental Protection Agency.

de Lima e Silva, C., Brennan, N., Brouwer, J., Commandeur, D., Verweij, R., van Gestel, C. (2017). Comparative toxicity of imidacloprid and thiacloprid to different species of soil invertebrates. Ecotoxicology, 26, 555-564.

Dittbrenner, N., Moser, I., Triebskorn, R., Capowiez, Y. (2011). Assessment of short and long-term effects of imidacloprid on the burrowing behaviour of two earthworm species (Aporrectodea caliginosa and Lumbricus terrestris) by using 2D and 3D post-exposure techniques. Chemosphere, 84, 1349-1355.

Doving, K. B. (1992). Assessment of animal behaviour as a method to indicate environmental toxicity. Comparative Biochemistry and Physiology, 100, 247-252.

Drobne, D., Blazic M., Van Gestel, C. A. M., Leser, V., Zidar, P., Jemec, A., Trebse, P. (2008). Toxicity of imidacloprid to the terrestrial isopod Porcellio scaber (Isopoda, Crustacea), Chemosphere, 71, 1326-1334. 
Edwards, C. A., Bohlen, P. J. (1992). The effects of toxic chemicals on earthworms. Reviews of Environmental Contamination and Toxicology, 125, 23-100.

Edwards, C. A., Fletcher K. E. (1988). Interactions between earthworms and microorganisms in organic-matter breakdown, Agriculture, Ecosystems and Environment., $24,235-247$.

EEC. (2003). SANCO/10329. Guidance Document on Terrestrial Ecotoxicology under Council Directive 91/414/EEC. Rev 2.

EFSA. (2012). Statement on the findings in recent studies investigating sub-lethal effects in bees of some neonicotinoids in consideration of the uses currently authorised in Europe. EFSA Journal, 10, 2752.

El-Naggar, J. B., Zidan, N. E. A. (2013). Field evaluation of imidacloprid and thiamethoxam against sucking insects and their side effects on soil fauna. Journal of Plant Protection Research, 53, 375e387.

Fernández-Gómez, M. J., Romero, E., Nogales, R. (2011). Impact of imidacloprid residues on the development of Eisenia fetida during vermicomposting of greenhouse plant waste. Journal of Hazardous Materials, 192(3), 1886-1889.

García, C., Hernández, T., Costa, F. (1997). Potential use of dehydrogenase activity as an index of microbial activity in degraded soils. Communications in Soil Science and Plant Analysis, 28, 123-134.

Ge, J., Xiao, Y., Chai, Y., Yan, H., Wu, R., Xin, X., Yu, X. (2018). Sub-lethal effects of six neonicotinoids on avoidance behavior and reproduction of earthworms (Eisenia fetida). Ecotoxicology and Environmental Safety, 162, 423-429.

Gibbons, D., Morrissey, C., Mineau, P. (2015). A review of the direct and indirect effects of neonicotinoids and fipronil on vertebrate wildlife. Environmental Science and Pollution Research, 22, 103-118.

Gill, P., Rao, S., Gupta, R., Singh, D., Dahiya, T., Lather, D., Kumar, N. (2021). Assessment of neonicotinoid insecticide imidacloprid LC50 and their toxicity parameters against earthworm (Eisenia fetida). Research Square.

Girolami, V., Mazzon, L., Squartini, A., Mori, N., Marzaro, M., Bernardo, A. D., Greatti, M., Giorio, C., Tapparo, A. (2009). Translocation of neonicotinoid insecticides from coated seeds to seedling guttation drops: a novel way of intoxication for bees. Journal of Economic Entomology, $102,1808-1815$.

Goulson, D. (2013). An overview of the environmental risks posed by neonicotinoid insecticides. Journal of Applied Ecology, 50, 977-987.

Gu, Y. H., Li, Y., Huang, X. F., Zheng, J. F., Yang, J., Diao, H., Yuan, Y., Xu, Y., Liu, M., Shi, H.J., Xu, W. P. (2013). Reproductive effects of two neonicotinoid insecticides on mouse sperm function and early embryonic development in vitro. PLoS One, 8, e70112.

Hallmann, C. A., Foppen, R. P. B., van Turnhout, C. A. M., de Kroon, H., Jongejans, E. (2014). Declines in insectivorous birds are associated with high neonicotinoid concentrations. Nature, 511, 341-343.

Han, W., Tian, Y., Shen, X. (2018). Human exposure to neonicotinoid insecticides and the evaluation of their potential toxicity: an overview. Chemosphere, 192, 59-65.

Hernández, D., Mansenét, V., Puiggrós Jové, J. M. (1999). Use of Confidor 200 SL in vegetable cultivation in Spain. Pflanzenschutz-Nachrichten Bayer, 52, 364-375.

Iwafune, T., Ogino, T., Watanabe, E. (2014). Water-based extraction and liquid chromatography - tandem mass spectrometry analysis of neonicotinoid insecticides and their metabolites in green pepper/tomato samples. Journal of Agricultural and Food Chemistry, 62, 2790-2796.

Jemec, A., Tisler, T., Drobne, D., Sepcic, K., Fournier, D., Trebse, P. (2007). Comparative toxicity of imidacloprid, of its commercial liquid formulation and of diazinon to a non- target arthropod, the microcrustacean Daphnia magna. Chemosphere, 68, 1408-1418.

Jeschke, P., Nauen, R., Michael Schindler, M., Elbert, A (2011). Overview of the status and global strategy for neonicotinoids. Journal of Agricultural and Food Chemistry, 59, 2897e2908.

Juraske, R., Castells, F., Vijay, A., Munoz, P., Antón, A. (2009). Uptake and persistence of pesticides in plants: measurements and model estimates for imidacloprid after foliar and soil application. Journal of Hazardous Materials, $165,683-689.6$

Kimura-Kuroda, J., Komuta, Y., Kuroda, Y., Hayashi, M., Kawano, H. (2012). Nicotine-like effects 467 of the neonicotinoid insecticides acetamiprid and imidacloprid on cerebellar neurons from neonatal rats. PLoS One, 7, e32432.

Kumar, S., Singh, S. M. (2017). Morpho-histopathological response of phorate - an organo-phosphorous pesticide on the integumentary musculature of an epigeic earthworm, Eisenia fetida. International Journal of Current Microbiology and Applied Sciences, 6(4), 2048-2053.

Little, E. E. (1990). Behavioral toxicology: stimulating challenges for a growing discipline. Environmental Toxicology and Chemistry, 9, 3-10.

Lopez-Antia, A., Ortiz-Santaliestra, M., Mougeot, F., Mateo, R. (2013). Experimental exposure of red-legged partridges (Alectoris rufa) to seeds coated with imidacloprid, thiram and difenoconazole. Ecotoxicology, 22, 125-138.

Luo, Y., Zang, Y., Zhong, Y. A., Kong, Z. M. (1999). Toxicological study of two novel pesticides on earthworm Eisenia foetida. Chemosphere, 39, 2347-2356.

Medrzycki, P., Montanari, R., Bortolotti, L., Sabatini, A. G., Maini, S., Porrini, C. (2003). Effects of imidacloprid administered in sub-lethal doses on honey bee behaviour. Laboratory tests. Bulletin of Insectology, 56, 59-62.

Niemeyer, J. C., Chelinho, S., Sousa, J. P. (2017). Soil ecotoxicology in Latin America: current research and perspectives. Environmental Toxicology and Chemistry, 36, $1795 \mathrm{e} 1810$.

Niva, C. C., Niemeyer, J. C., Júnior, F. M., Nunes, M. E., De Sousa, D. L., Aragao, C. W., Sautter, K. D., Espindola, E. G., Sousa, J. P., Rombke, J. (2016). Soil ecotoxicology in Brazil is taking its course. Environmental Science and Pollution Research, 23, 11363e11378.

OECD Guideline for Testing of Chemicals. (1984). "Earthworm, Acute Toxicity Tests". Organization for Economic Co-operation and Development, Paris, 207. https://www.oecd.org/chemicalsafety/riskassessment/1948293.pdf

Pisa, L. W., Amaral-Rogers, V., Belzunces, L. P., Bonmatin, J. M., Downs, C. A., Goulson, D., Kreutzweiser, D. P., Krupke, C., Liess, M., McField, M., Morrissey, C. A., Noome, D. A., Settele J., Simon-Delso, N., Stark, J. D., Van Der Sluijs, J. P., Van Dyck, H., Wiemers, M. (2015) Effects of neonicotinoids and fipronil on non-target invertebrates. Environmental Science and Pollution Research, 22, 68-102.

Renaud, M., Akeju, T., Natal-da-Luz, T., Leston, S., Rosa, J., Ramos, F., Sousa, J., Azevedo-Pereira, H. (2018). Effects of the neonicotinoids acetamiprid and thiacloprid in their commercial formulations on soil fauna. Chemosphere, 194, 85-93.

Scherrer, E. (1992). Behavioural responses as indicator of environmental alterations: approaches, results, developments. Journal of Applied Ichthyology, 8, 122-131.

Simon-Delso, N., Amaral-Rogers, V., Belzunces, L. P., Bonmatin, J. M., Chagnon, M., Downs, C., Furlan, L., Gibbons, D. W., Giorio, C., Girolami, V., Goulson, D., Kreutzweiser, D. P., Krupke, C. H., Liess, M., Long, E., McField, M., Mineau, P., Mitchell, E. A. D., Morrissey, C. A., Noome, D. A., Pisa, L., Settele, J., Stark, J.D., Tapparo, A., Van Dyck, H., Van Praagh, J., Van der Sluijs, J. P., Whitehorn, P. R., Wiemers, M. (2015). Systemic 
insecticides (neonicotinoids and fipronil): trends, uses, mode of action and metabolites. Environmental Science and Pollution Research, 22, 5e34.

Smith, R. G., Atwood, L. W., Morris, M. B., Mortensen, D. A., Koide, R. T. (2016). Evidence for indirect effects of pesticide seed treatments on weed seed banks in maize and soybean. Agriculture, Ecosystems and Environment, 216, $269 \mathrm{e} 273$.

Song, S., Zhang, C., Chen, Z., He, F., Wei, J., Tan, H., Li, X. (2018). Simultaneous determination of neonicotinoid insecticides and insect growth regulators residues in honey using LC-MS/MS with anion exchanger-disposable pipette extraction. Journal of Chromatography A, 1557, 51-61.

Spurgeon, D. J., Weeks J. M., Van Gestel, C. A. (2003). A summary of eleven years progress in earthworm ecotoxicology: The 7th International Symposium on Earthworm Ecology. Cardiff, Wales, 2002. Pedobiologia, 47(5), 588-606.

Stanley, D. A., Garratt, M. P. D., Wickens, J. B., Wickens, V. J., Potts, S. G., Raine, N.E. (2015). Neonicotinoid pesticide exposure impairs crop pollination services provided by bumblebees. Nature, 528, 548-550.

Stenersen, J., (1979). Action of pesticides on earthworms. Part I: The toxicity of cholinesterase-inhibiting insecticides to earthworms as evaluated by laboratory tests. Pesticide Science, 10(1), 66-74.

Suchail, S., Guez, D., Belzunces, L. P. (2001). Discrepancy between acute and chronic toxicity induced by imidacloprid and its metabolites in Apis mellifera. Environmental Toxicology and Chemistry, 20, 2482-2486.

Tapparo, A., Marton, D., Giorio, C., Zanella, A., Soldà, L., Marzaro, M., Vivan, L., Girolami, V. (2012). Assessment of the environmental exposure of honeybees to particulate matter containing neonicotinoid insecticides coming from corn coated seeds. Environmental Science and Technology, 46, 2592-2599.

Tomizawa, M., Casida, J. E. (2005). Neonicotinoid insecticide toxicology: mechanisms of selective action. Annual Review of Pharmacology and Toxicology, 45, 247-268.

Ueyama, J., Harada, K. H., Koizumi, A., Sugiura, Y., Kondo, T., Saito, I., Kamijima, M. (2015). Temporal levels of urinary neonicotinoid and dialkylphosphate concentrations in Japanese women between 1994 and 2011. Environmental Science and Technology, 49, 14522-14528.

van der Sluijs, J. P., Simon-Delso, N., Goulson, D., Maxim, L., Bonmatin, J. M., Belzunces, L. P. (2013). Neonicotinoids, bee disorders and the sustainability of pollinator services. Current Opinion in Environmental Sustainability, 5. 293-305.

van Gestel, C., de Lima e Silva, C., Lam, T., Koekkoek, J., Lamoree, M., Verweij, R. (2017). Multigeneration toxicity of imidacloprid and thiacloprid to Folsomia candida. Ecotoxicology, 26, 320-328.

Velki, M., Ecimovic, S. (2015). Changes in exposure temperature lead to changes in pesticide toxicity to earthworms: a preliminary study. Environmental Toxicology and Pharmacology, 40, 774e784.

Wang, J. H. (2012). The combined stress effects of atrazine and cadmium on the earthworm Eisenia fetida. Environmental Toxicology and Chemistry, 31(9), 2035-2040.

Wang, J., Wang, G., Zhu, L. (2016). DNA damage and oxidative stress induced by imidacloprid exposure in the earthworm Eisenia fetida. Chemosphere, 144, 510-517.

Wang, L., Liu, T., Liu, F., Zhang, J., Wu, Y., Sun, H. (2015). Occurrence and profile characteristics of the pesticide imidacloprid, preservative parabens, and their metabolites in human urine from rural and urban China. Environmental Science and Technology, 49, 14633-14640.

Wang, Y., Cang, T., Zhao, X., Yu, R., Chen, L., Wu, C. (2012). Comparative acute toxicity of twenty-four insecticides to earthworm, Eisenia fetida. Ecotoxicology and Environmental Safety, 79, 122-128.

Whitehorn, P. R., O'Connor, S., Wackers, F. L., Goulson, D. (2012). Neonicotinoid pesticide reduces bumble bee colony growth and queen production. Science, 336, 351-352.

WHO (2006). Recommended classification of pesticides by hazard and guidelines to the classification, World Health Organization,

Geneva. https://apps.who.int/iris/handle/10665/44271

Xu, J., Zhang, P., Mu, H., Gao, M. L. (2006). Toxicity Effect of Combined Contamination of Two Herbicides to Earthworm. Journal of Agro-Environment Science, 5, 018.

Zang, Y., Zhong, Y., Luo, Y., Kong, Z. M. (2000). Genotoxicity of two novel pesticides for the earthworm, Eisenia foetida. Environmental Pollution, 108, 271-278.

Zhang, Q., Zhang, B., Wang, C. (2014). Ecotoxicological effects on the earthworm Eisenia fetida following exposure to soil contaminated with imidacloprid. Environmental Science and Pollution Research, 21, 12345-12353. 